\title{
Telenomus remus, a Candidate Parasitoid for the Biological Control of Spodoptera frugiperda in Africa, is already Present on the Continent
}

\author{
Marc Kenis ${ }^{1, *}$, Hannalene du Plessis ${ }^{2}\left(\mathbb{0}\right.$, Johnnie Van den Berg ${ }^{2}{ }^{(D}$, Malick Niango Ba ${ }^{3}$, \\ Georg Goergen ${ }^{4}$, Koffi Eric Kwadjo ${ }^{5}$, Ibrahim Baoua ${ }^{6}$, Tadele Tefera ${ }^{7}$, Alan Buddie ${ }^{8}$, \\ Giovanni Cafà ${ }^{8}$ D , Lisa Offord ${ }^{8}$, Ivan Rwomushana ${ }^{9}(\mathbb{D}$ and Andrew Polaszek 10 \\ 1 CABI, 1 Rue des Grillons, 2800 Delémont, Switzerland \\ 2 IPM program, Unit for Environmental Sciences and Management, North-West University, \\ 2520 Potchefstroom, South Africa; Hannalene.DuPlessis@nwu.ac.za (H.d.P.); \\ Johnnie.VanDenBerg@nwu.ac.za (J.V.d.B.) \\ 3 ICRISAT, BP 12404 Niamey, Niger; B.Malick@cgiar.org \\ 4 International Institute of Tropical Agriculture (IITA), 08 BP 0932 Tri Postal, Cotonou, Benin; \\ g.goergen@cgiar.org \\ 5 University Nangui Abrogoua, 01 BP 3594 Abidjan 01, Côte d'Ivoire; kwadjoeric.sn@univ-na.ci \\ 6 University Dan Dicko Dankoulodo de Maradi, BP 465 Maradi, Niger; baoua.ibrahim@gmail.com \\ 7 International Center of Insect Physiology \& Ecology (icipe), P.O. Box 30772-00100 Addis Ababa, Ethiopia; \\ ttefera@icipe.org \\ 8 CABI, Bakeham Lane, Egham TW20 9TY, UK; a.buddie@cabi.org (A.B.); g.cafa@cabi.org (G.C.); \\ 1.offord@cabi.org (L.O.) \\ 9 CABI Limuru Road, Muthaiga, PO Box 633-00621 Nairobi, Kenya; I.Rwomushana@cabi.org \\ 10 Natural History Museum, London SW75BD, UK; A.Polaszek@nhm.ac.uk \\ * Correspondence: m.kenis@cabi.org; Tel.: +41-32-4214884
}

Received: 5 March 2019; Accepted: 25 March 2019; Published: 29 March 2019

\begin{abstract}
The fall armyworm, Spodoptera frugiperda, a moth originating from tropical and subtropical America, has recently become a serious pest of cereals in sub-Saharan Africa. Biological control offers an economically and environmentally safer alternative to synthetic insecticides that are being used for the management of this pest. Consequently, various biological control options are being considered, including the introduction of Telenomus remus, the main egg parasitoid of S. frugiperda in the Americas, where it is already used in augmentative biological control programmes. During surveys in South, West, and East Africa, parasitized egg masses of S. frugiperda were collected, and the emerged parasitoids were identified through morphological observations and molecular analyses as T. remus. The presence of $T$. remus in Africa in at least five countries provides a great opportunity to develop augmentative biological control methods and register the parasitoid against $S$. frugiperda. Surveys should be carried out throughout Africa to assess the present distribution of T. remus on the continent, and the parasitoid could be re-distributed in the regions where it is absent, following national and international regulations. Classical biological control should focus on the importation of larval parasitoids from the Americas.
\end{abstract}

Keywords: biological control; egg parasitism; fall armyworm; invasive species; maize; Spodoptera frugiperda; Telenomus remus

\section{Introduction}

The fall armyworm, Spodoptera frugiperda (JE Smith) (Lepidoptera: Noctuidae) is a highly destructive pest of cereals, and is a native of the tropical and sub-tropical regions of North, Central, 
and South America [1]. First detected on the African continent in January 2016 in Nigeria [2], S. frugiperda has now been reported in almost all of sub-Saharan Africa [3]. Recently published pest distribution and climatic suitability models have indicated that the environmental requirements for this pest to establish itself permanently are present through large parts of Africa and Asia and some parts of Europe [4,5]. The pest's distribution has reached the southern fringes of the Sahara, and it has most recently been reported from several states in India [6,7], as well as Yemen, Myanmar, Thailand, and Sri Lanka [8]. Indeed, it is likely that it will spread further north to Europe and other countries in Asia. The invasion of $S$. frugiperda threatens the food security of more than 200 million people in Africa whose main staple crop is maize. Based on preliminary estimates in 12 African maize-producing countries, in the absence of proper control methods, $S$. frugiperda has the potential to cause maize yield losses of 8.3 to 20.6 million tonnes per annum. The value of these losses is estimated at between US\$ 2.5 to 6.2 billion, with over US\$ 13 billion worth of crops at risk [9]. In addition, the pest, known to be highly polyphagous, is likely to jeopardize the trade and export of other crops from the invaded regions.

Following the invasion of S. frugiperda into Africa, emergency responses have been geared towards the use of chemical insecticides [10]. The frequent application of different classes of insecticides is unsustainable in the long-run because it leads to the development of insecticide resistance, increases production costs, and causes biodiversity and environmental impacts as well as health risks to the growers and consumers [11,12]. It also disrupts IPM measures, such as biological control, targeted at other cereal pests $[9,13]$. Therefore, it is important to minimize the use of insecticides, especially the highly hazardous and broad-spectrum ones, and to develop, promote, and deploy proven and sustainable IPM technologies against S. frugiperda.

Biological control, i.e., the use of natural enemies to control a pest, is central to the development of IPM systems. Three different biological control strategies can be envisaged against $S$. frugiperda in Africa [14]. Firstly, natural enemies could be imported from the native area of the pest for release and permanent establishment in Africa (classical biological control). Secondly, natural enemies could be mass produced for regular releases and temporary control (augmentative biological control). Thirdly, the action of natural enemies already present in the crops could be enhanced by the application of various cultural practices including the use of selective insecticides (conservation biological control).

Parasitoids are natural enemies most commonly used against insect pests [15]. Over 150 parasitoid species have been reported to attack $S$. frugiperda in its native range in the Americas $[13,16,17]$. Among these, Telenomus remus Nixon (Hymenoptera: Platygastridae) is an egg parasitoid of various Lepidoptera species, originating from peninsular Malaysia (but see the discussion section, under "Taxonomy of Telenomus remus"). It was introduced against Spodoptera spp. to various parts of the world, including India, Pakistan, Australia, New Zealand, the Caribbean, Colombia and Venezuela. The parasitoid is now found in most of the distribution range of S. frugiperda in the Americas [18]. In Africa, it was also released in the Cape Verde Islands in the early 1980s, but its establishment has not been confirmed [19]. In the Americas, parasitism due to natural populations of T. remus is moderate but it is used successfully as an augmentative biological control agent in several countries [20-22]. T. remus can be produced under laboratory conditions on $S$. frugiperda or other hosts and released in the field [10,20,23]. A female produces an average of 270 eggs during her lifespan, usually laid individually in each host egg, avoiding superparasitism [20]. They are also able to parasitize the whole egg mass, whereas other egg parasitoids such as Trichogramma spp. tend to parasitize only the external layer [24]. Augmentative releases of T. remus in maize fields can result in 80-100\% parasitism, providing full control of $S$. frugiperda $[20-22,25]$. The main challenge for a wider utilisation of T. remus is the difficulty to mass produce its natural hosts, and the need for developing rearing systems on factitious hosts $[23,26]$. Nevertheless, T. remus is considered for introduction into Africa as part of the response to $S$. frugiperda [10]. 
In this paper, we report on the observation that T. remus is already present in Africa, speculate how it might have arrived on the continent, and assess the potential for its use in augmentative biological control in Africa. This is the first report of an egg parasitoid of S. frugiperda in the open field in Africa.

\section{Materials and Methods}

\subsection{Field Sampling}

Parasitized eggs of $S$. frugiperda were obtained from eight sites in five countries: Benin (2 sites), Côte d'Ivoire (1), Kenya (1), Niger (2), and South Africa (2), in 2017 and 2018 (Table 1). These collections were made as part of different, unrelated projects, during $S$. frugiperda population surveys or for sampling egg masses for laboratory rearing. Quantitative data on parasitism were not collected, as it was not the primary objective of these surveys. Sampling and rearing techniques varied between sampling sites, but in all cases egg masses of $S$. frugiperda were brought to the laboratory and held in small containers. Egg parasitoids that emerged from egg masses were removed from the containers and killed by immersion in 70-96\% alcohol. Larvae from the non-parasitized eggs in the same egg mass were reared until adult emergence to confirm the identity of the hosts.

Table 1. Details of the sampling sites, numbers, and accession numbers of specimens sequenced.

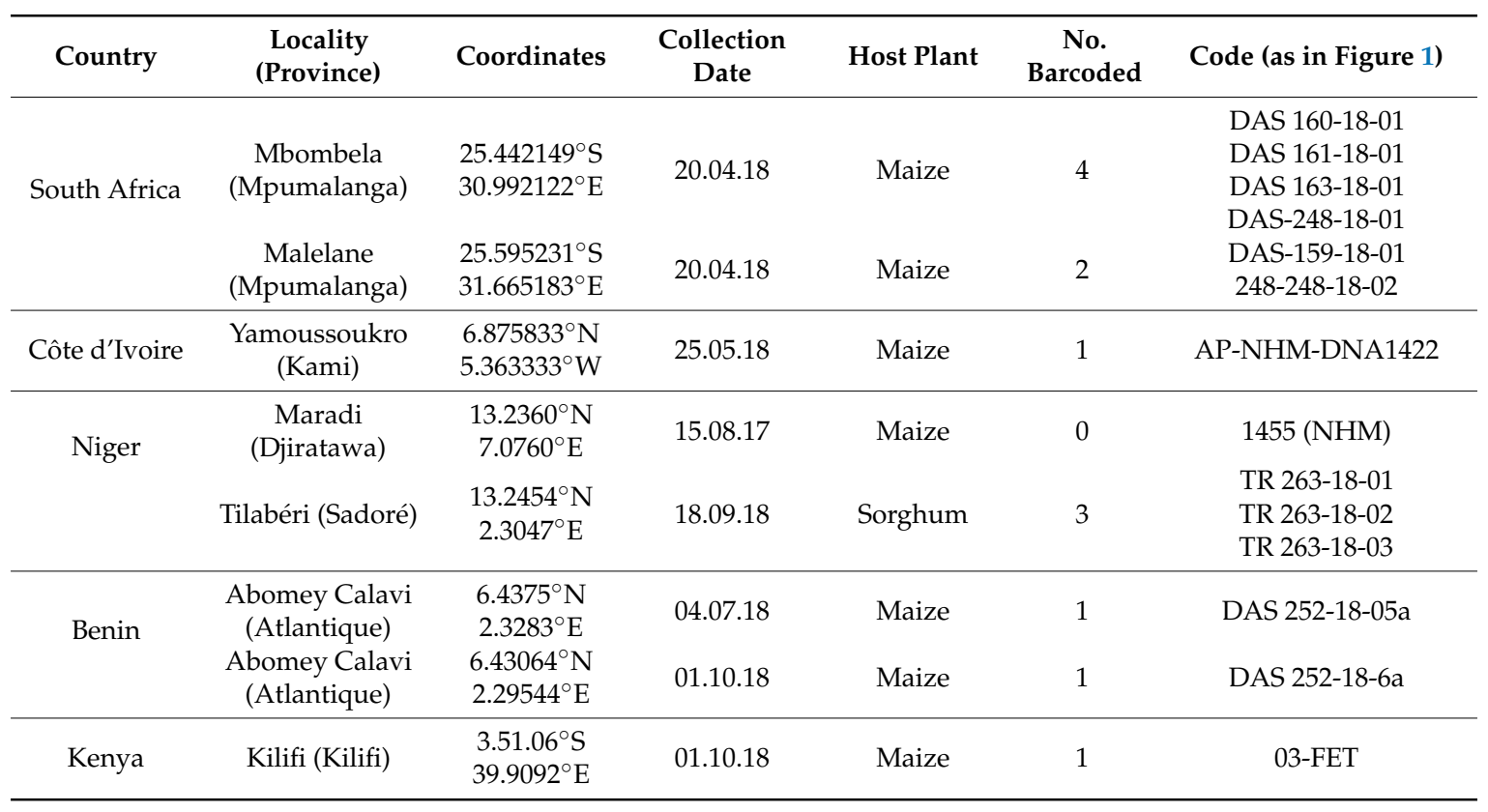

Samples of the egg parasitoids were sent to the Centre for Agriculture and Bioscience International (CABI) and the Natural History Museum, London, UK (NHMUK) for morphological and molecular analyses. Voucher specimens of egg parasitoids from all localities are deposited permanently in NHMUK, the North-West University, Potchefstroom, South Africa; and CABI, Delémont, Switzerland.

\subsection{Morphological Analysis}

Identifying Telenomus species is particularly difficult among other minute parasitoids. Females tend to appear very similar between species, with only very few useful morphological characters. Male genitalia, however, provide fairly reliable characters for species identification. Specimen preparation and dissection and mounting of genitalia are relatively straightforward [27], and can be done successfully on specimens from which DNA has already been extracted [28]. Several male specimens (>3) from each locality were dissected and examined. 


\subsection{Molecular Analyses}

Thirteen specimens, obtained from all but one site (Maradi, Niger), were analysed (Table 1). To obtain barcodes (around $600 \mathrm{bp}$ of the mitochondrial gene (mtDNA) cytochrome oxidase c subunit 1 (COI)) from the samples, we followed the protocols described in [29]. These included the isolation of DNA from fragments of the abdomen of each specimen, by adding $20 \mu \mathrm{L}$ of microLYSIS ${ }^{\circledR}$-PLUS (MLP; Microzone Ltd., Haywards Heath, UK) to the material. The suspension was macerated with a sterile micropestle (VWR International Ltd., UK) to facilitate the disruption of the exoskeleton and tissues of the samples. DNA was then liberated into the MLP by placing the sample tubes in a thermal cycler and subjecting them to the heat profile recommended by the manufacturer for difficult samples. PCR reactions were carried out using a Hybaid PCR Express thermal cycler in heated-lid mode. Amplifications were carried out in $0.5 \mathrm{ml}$ microcentrifuge tubes in $20 \mu \mathrm{L}$ reactions containing: $1 \mu \mathrm{L}$ MLP DNA extract; primers LCO1490 and HCO2198 (5'-GGTCAACAAATCATAAAGATATTGG-3' and 5'-TAAACTTCAGGGTGACCAAAAAATCA-3', respectively; [30]), each at $150 \mathrm{nM}$; and $10 \mu \mathrm{L}$ of MegaMix-Royal (Microzone Ltd, Haywards Heath, UK) mastermix solution, containing optimized mixture of Taq polymerase in $2 \times$ enhancing buffer $(6 \mathrm{mM} \mathrm{MgCl}$ ), with $400 \mu \mathrm{M}$ dNTPs and blue MiZN loading dye. Reactions were made up to a final volume of $20 \mu \mathrm{L}$ with sterile molecular grade $\mathrm{H}_{2} \mathrm{O}$. PCR reactions were preincubated for $5 \mathrm{~min}$ at $95^{\circ} \mathrm{C}$ followed by 39 cycles of $30 \mathrm{~s}$ at $94{ }^{\circ} \mathrm{C}, 30 \mathrm{~s}$ at $51{ }^{\circ} \mathrm{C}$, and $75 \mathrm{~s}$ at $72{ }^{\circ} \mathrm{C}$. Samples were finally incubated for $10 \mathrm{~min}$ at $72{ }^{\circ} \mathrm{C}$ followed by chilling at $10^{\circ} \mathrm{C}$. A second round of amplification (i.e., "reamplification") was undertaken as follows: $1 \mu \mathrm{L}$ of each of the above PCR products was used as a template. The reaction was carried out under the same conditions, with the exception of the number of cycles, which were reduced to 30. PCR products were visualized with gel electrophoresis, purified by microCLEAN (Microzone Ltd., Haywards Heath, $\mathrm{UK}$ ), and resuspended in $15 \mu \mathrm{L}$ sterile molecular grade $\mathrm{H}_{2} \mathrm{O}$. After sequencing reactions, excess unincorporated dye terminators were removed by means of DyeEx 2.0 (Qiagen, UK) gel filtration columns, according to the manufacturer's instructions. Eluted samples were resuspended in $16 \mu \mathrm{L}$ highly deionized formamide (HiDi ${ }^{\mathrm{TM}}$; ThermoFisher Scientific, Gloucester, UK). Sanger sequencing was carried out on an ABI 3130 Genetic Analyzer (ThermoFisher Scientific, Gloucester, UK) in accordance with the manufacturer's instructions.

Sequences were aligned using the multiple sequence alignment plug-in CLUSTALW in MEGA7 [31]. Sequences obtained in this study were compared with authenticated sequences available from the Barcoding of Life Data system [32] and additional sequences from the GenBank ${ }^{\circledR}$ data base [33] and trimmed to size. The evolutionary history was inferred by using the maximum likelihood method based on the Tamura-Nei model [34]. Initial tree(s) for the heuristic search were obtained automatically by applying Neighbor-Join and BioNJ algorithms to a matrix of pairwise distances estimated using the maximum composite likelihood (MCL) approach, and then selecting the topology with superior log likelihood value. Codon positions included were $1 \mathrm{st}+2 \mathrm{nd}+3 \mathrm{rd}+$ noncoding. All positions containing gaps and missing data were eliminated. Trees were drawn to scale, with branch lengths measured in the number of substitutions per site. The bootstrap consensus tree inferred from 1000 replicates is taken to represent the evolutionary history of the taxa analysed [35]. Branches corresponding to partitions reproduced in less than $50 \%$ bootstrap replicates are collapsed. The percentage of replicate trees in which the associated taxa clustered together in the bootstrap test (1000 replicates) are shown next to the branches [35]. Evolutionary analyses were conducted in MEGA7 [31].

\section{Results}

Morphological analysis of several male specimens from each of the eight collection localities suggested identical species with almost no variation. Specimens were compared with a series of T. remus from many localities in Asia and the Americas, and found to be conspecific. A single specimen of T. remus in the NHMUK collection from Kenya, reared from eggs of Spodoptera triturata (Walker), was identified as T. remus by the last author in 1988 [36]. Records of T. remus from Serbia (Europe) in the Hymenoptera online database [37] are actually from Venezuela. The specimen data read as follows: 
"Ex. huevo de Spodoptera spp.; Cria masiva Lab. Serbio; (Barquisimeto, Venezuela-Lara-m.) (30.VIII.1990)". "Serbio" is clearly the source of the error.

The thirteen barcode sequences derived from this study gave $100 \%$ match to each other and were identified by comparison with those available from the BOLD database. The sequences were deposited in GenBank with accession numbers MH681660-3 and MK533746-7; MK533750-4; MK533757-8. Over $99 \%$ of the pairs of bases were identical to a series of 31 specimens in BOLD identified as Telenomus remus. Matches varied from 99.05\% to 99.63\%, with 27 specimens from Bangladesh, and were 99.62\%, 99.56\%, 99.56\%, and 99.34\% with single specimens from Pakistan, Ecuador, USA (Florida), and Honduras, respectively, but only $96.3 \%$ with a T. remus specimen from India (Kerala). The samples from Honduras, Ecuador, and Florida are those described in detail in Hay-Roe et al. [38]. The most closely-related Telenomus species, for which barcodes are publicly available, is Telenomus goniopis, which overlaps with our specimens at 91.17-91.33\% (Figure 1). There is a strong probability that the "T. remus" sequence from India is based on a misidentification.

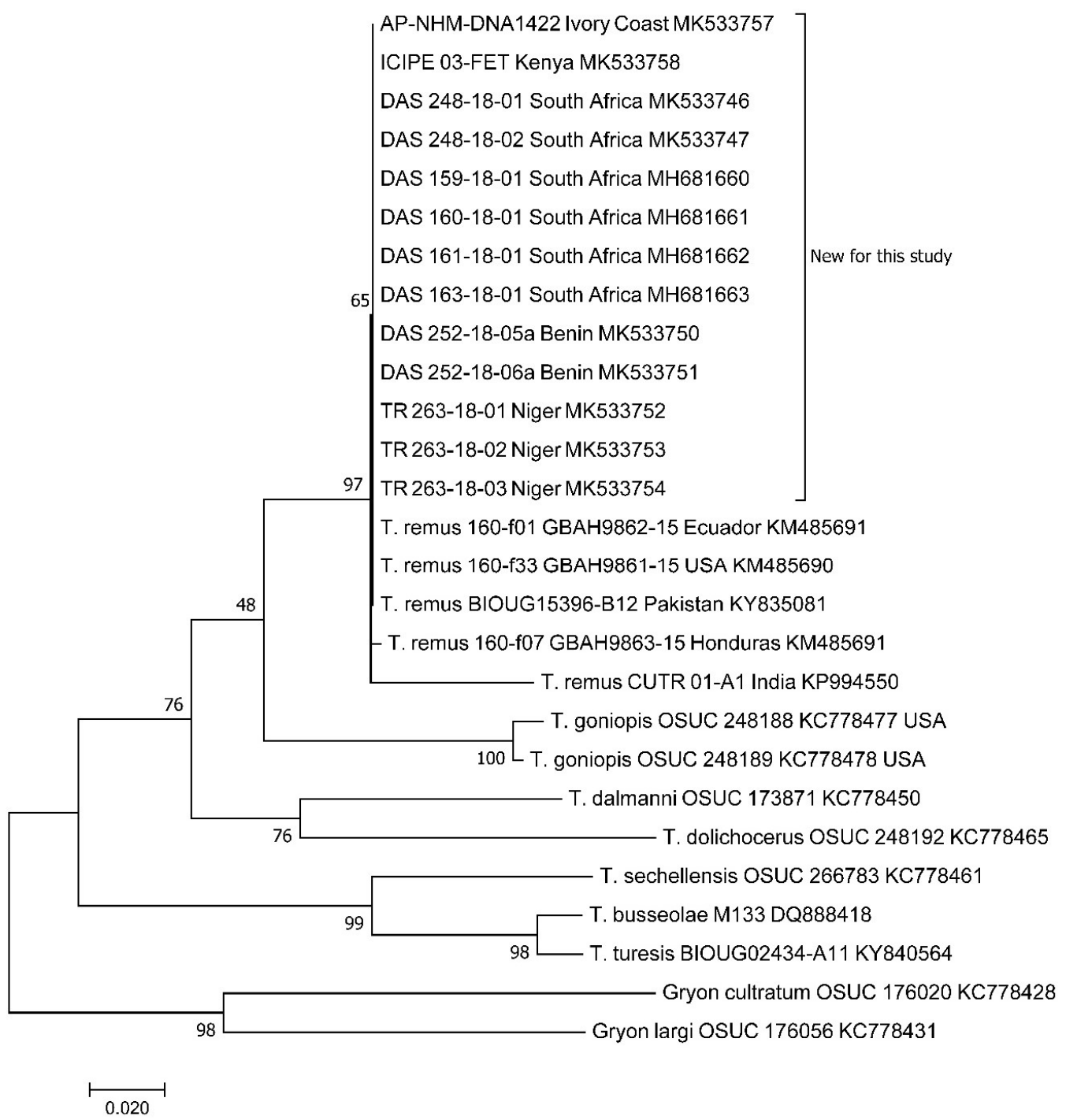

Figure 1. Molecular Phylogenetic analysis of Telenomus remus and related species by maximum likelihood method. The tree with the highest log likelihood (-1910.13) is shown. The percentage of trees in which the associated taxa clustered together is shown next to the branches. The analysis involved 27 nucleotide sequences. There were a total of 382 positions in the final dataset. The 13 specimens analysed in this study are indicated as "New for this study", and their codes are indicated in Table 1. 


\section{Discussion}

\subsection{Presence of T. remus in Africa}

This study shows that a species identified from both morphology and DNA sequences as T. remus has been attacking $S$. frugiperda eggs in at least five countries in West, East, and Southern Africa, and eggs of the lawn worm, $S$. triturata, in Kenya. The genetic distance between the specimens from Africa and the numerous Asian and American T. remus specimens available in the barcode datasets is sufficiently small $(<1 \%)$ to conclude that it is the same species as the one that was released previously in South Asia and the Americas. Even though differences between intra- and interspecific divergence strongly vary between taxonomic groups, and genetic distances have to be used with caution to define species, Virgilio et al. [39] observed that 95\% of mean interspecific congeneric distances in insects were found in the interval 2.47-21.00\%. In an unpublished thesis, Bowers [40] suggested that, in Telenomus spp., intra-specific barcode divergences were below $1.6 \%$ whereas interspecific divergences were greater than $5.6 \%$.

It is not known when and how T. remus arrived in Africa, but it certainly arrived before S. frugiperda since a specimen was collected in Kenya in 1988. This species parasitizes several Spodoptera spp. and some other Noctuidae [41], and could have remained unnoticed on other hosts for a long time because the adults of Telenomus spp. are extremely small and difficult to distinguish and identify on a morphological basis [38].

\subsection{Implications for the Biological Control of S. frugiperda}

No matter the pathway of introduction, the presence of T. remus has important implications for the biological control of $S$. frugiperda in Africa. Firstly, it shows that the parasitoid complex of S. frugiperda in Africa should be studied in detail before the introduction of exotic parasitoids. Prior to this report, the only published record of field parasitism of S. frugiperda in Africa was by Sisay et al. [42] in East Africa, but they did not report T. remus or any other egg parasitoid, with the exception of the egg-larval parasitoid Chelonus curvimaculatus Cameron, found at two locations. There are efforts underway for importing parasitoids from the native range of $S$. frugiperda for releases in Africa, either for permanent establishment and control or for augmentative biological control. Telenomus remus is high on the list of priority species to introduce, because it is the main egg parasitoid of $S$. frugiperda in its native range and, especially, because it is already successfully used in augmentative biological control programs and therefore can easily be adapted to the African situation. Our finding that T. remus is already extant in Africa suggests that importation efforts should focus on larval or pupal parasitoids, since the other known egg parasitoids of $S$. frugiperda in America (mostly Trichogramma spp.) are too polyphagous to be considered for introduction into Africa and not as effective.

A specific research programme should be developed for T. remus in Africa. Surveys for egg parasitoids should be carried out to determine how widespread T. remus is in Africa, and parasitism rates should be properly assessed to evaluate its impact on $S$. frugiperda populations. A phylogeographic study using molecular tools, such as in [43], would help in clarifying the history of T. remus in Africa. These surveys should also determine which other African Lepidoptera species served as host for T. remus prior to the arrival of $S$. frugiperda. For instance, the single record of $T$. remus on $S$. triturata needs to be followed up closely. Knowing its host range in African agroecosystems may also support the development of measures to enhance the parasitoid in a conservation biological control programme. Surveys for egg parasitism in Africa may also reveal that other Telenomus spp. have adopted $S$. frugiperda, in which case their interactions with T. remus should be investigated. In Africa, at least 10 Telenomus species have been found on cereal stem borers and have been well studied $[27,44]$. In contrast, those attacking Spodoptera spp. are largely unknown.

If the distribution range of T. remus in Africa does not fully overlap that of $S$. frugiperda, the egg parasitoid could be redistributed in the regions where it is absent, following national and international regulations for introduction of natural enemies. Climate modelling, similar to [4] for S. frugiperda, 
should determine whether all areas in Africa are suitable for its establishment. Several studies have assessed its climatic requirements, e.g., [26,45-47], which should allow for the development of such models. Methods to use T. remus in augmentative biological control programmes should be developed based upon those used in the Americas $[10,20,23,25,26]$, and T. remus should be registered as biological control agent against $S$. frugiperda. However, local specificities need to be considered, e.g., the fact that, in the Americas, maize is often planted in large monocultures while most of the maize in Africa is cultivated by smallholder farmers in mixed systems. Challenges may also be encountered in the mass production of the parasitoid due to the inherent difficulty of rearing T. remus on its natural host and the need of a factitious host for mass production $[23,26,48]$. Since the T. remus populations established in Africa may have never encountered S. frugiperda until recently, and because it might have become adapted to completing development in yet unknown hosts, it may be less efficient on this host than populations from the Americas that have evolved with $S$. frugiperda during, at least, the past 40 years. Therefore, it would be interesting to compare T. remus populations of African and American origins regarding their performance on S. frugiperda in quarantine. If American populations appear significantly more efficient than the African populations, the introduction of American populations could be considered.

\subsection{Taxonomy of Telenomus remus}

Telenomus remus was described from Ulu Gombak, just NE of Kuala Lumpur, Malyasia [49]. In the original description, Nixon states: "This species is probably Telenomus spodopterae Dodd, which was described from four females labelled "from eggs of a moth Spodoptera sp. on sugar beet, Krebet, Java, 23.7.1913". Nixon was reluctant to use Dodd's name, as he considered the original description inadequate and thought there might be an important difference in the fore wing proportions. At least two more Telenomus species appear morphologically indistinguishable from T. remus (including male genitalia): Telenomus nawai Ashmead was described from Gifu, Japan [50]; and T. soudanensis (Risbec) was described from West Africa (probably Mali) [51]. There is some likelihood that all of these named species are conspecific [44]. Further research to establish the identities and possible conspecificity of the three described species would focus on DNA sequencing of specimens collected recently from the three type localities. Two independent studies have found mating incompatibility between two apparent species: Raveendranath [52] found a population from Hawaii was reproductively incompatible with one from Barbados, and Arakaki et al. [53] found an isolated population of T. nawai in Japan that is thelytokous due to Wolbachia infection. Further research is needed to clarify the status of these species.

\section{Conclusions}

This study showed that T. remus, the main egg parasitoid of Spodoptera frugiperda in the Americas that is considered for introduction into Africa, has now been found in East, South, and West Africa. This finding has important implications for the development of augmentative biological control and IPM programmes against S. frugiperda in Africa.

Author Contributions: Insect collection, H.d.P., J.V.d.B., M.B., G.G., K.E.K., I.B., and T.T.; morphological identifications, A.P.; molecular and genetic analyses, A.B., G.C., and L.O.; writing-original draft preparation, M.K., A.B., I.R., and A.P.; writing-review and editing, H.d.P., J.V.d.B., M.B., G.G., K.E.K., I.B. G.C., and L.O.; supervision, M.K.

Funding: This study was financially supported by the Department for International Development (DFID), UK and the Directorate-General for International Cooperation (DGIS), Netherlands through CABI's Action on Invasives Programme. The Maize Trust contributed to funding of field surveys of S. frugiperda in South Africa. The sample collection in Kenya was supported by funds from USAID Feed the Future IPM Innovation Lab, Virginia Tech (AID-OAA-L-15-00001) and in Benin by the Gesellschaft für Internationale Zusammenarbeit (GIZ).

Conflicts of Interest: The authors declare no conflict of interest. 


\section{References}

1. Sparks, A.N. A review of the biology of the fall armyworm. Fla. Entomol. 1979, 62, 82-87. [CrossRef]

2. Goergen, G.; Kumar, P.L.; Sankung, S.B.; Togola, A.; Tamò, M. First report of outbreaks of the fall armyworm Spodoptera frugiperda (JE Smith) (Lepidoptera, Noctuidae), a new alien invasive pest in West and Central Africa. PLOS ONE 2016, 11. [CrossRef]

3. FAO. Briefing Note on FAO Actions on Fall Armyworm in Africa; FAO: Rome, Italy; Available online: www.fao. org/3/a-bt415e.pdf (accessed on 20 February 2019).

4. Du Plessis, H.; Van den Berg, J.; Kriticos, D.J.; Ota, N. Spodoptera frugiperda. (Fall Armyworm), CLIMEX modelling. CSIRO-InSTePP Pest Geography 2018. ResearchGate. Available online: https:/ / www.researchgate.net/publication/327423712_Spodoptera_frugiperde_-_CLIMEX_modelling_ du_Plessis_van_den_Berg_Ota_Kriticos_2018_CSIRO-InSTePP_Pest_Geography_June_2018_Canberra (accessed on 26 March 2019).

5. Early, R.; González-Moreno, P.; Murphy, S.T.; Day, R. Forecasting the global extent of invasion of the cereal pest Spodoptera frugiperda, the fall armyworm. NeoBiota 2018, 40, 25-50. [CrossRef]

6. Ganiger, P.C.; Yeshwant, H.M.; Muralimohan, K.; Vinay, N.; Kumar, A.R.V.; Chandrashekara, K. Occurrence of the new invasive pest, fall armyworm, Spodoptera frugiperda (J.E. Smith) (Lepidoptera: Noctuidae), in the maize fields of Karnataka, India. Current Sci. 2018, 115, 621-623.

7. Sharanabasappa, D.; Kalleshwaraswamy, C.M.; Asokan, R.; Mahadeva Swamy, H.M.; Marutid, M.S.; Pavithra, H.B.; Hegde, K.; Navi, S.; Prabhu, S.T.; Goergen, G. First report of the fall armyworm, Spodoptera frugiperda (J. E. Smith) (Lepidoptera: Noctuidae), an alien invasive pest on maize in India. Pest. Manage. Hort. Ecosys. 2018, 4, 23-29.

8. CABI Fall Armyworm Portal. Available online: https://www.cabi.org/isc/fallarmyworm (accessed on 26 March 2019).

9. Day, R.; Abrahams, P.; Bateman, M.; Beale, T.; Clottey, V.; Cock, M.; Colmenarez, Y.; Corniani, N.; Early, R.; Godwin, J.; et al. Fall armyworm: Impacts and implications for Africa. Outlooks Pest Manage 2017, 28, 196-201. [CrossRef]

10. Prasanna, B.M.; Huesing, J.E.; Eddy, R.; Peschke, V.M. Fall Armyworm in Africa: A Guide for Integrated Pest Management, 1st ed.; CIMMYT: Mexico City, Mexico, 2018.

11. Abrahams, P.; Bateman, M.; Beale, T.; Clottey, V.; Cock, M.; Colmenarez, Y.; Corniani, N.; Day, R.; Early, R.; Godwin, J.; et al. Fall Armyworm: Impacts and Implications for Africa. Evidence Note (2); Report to DFID. Available online: https://www.cabi.org/ISC/FullTextPDF/2018/20187200428.pdf (accessed on 26 March 2019).

12. Yu, S.J.; Nguyen, S.N.; Abo-Elghar, G.E. Biochemical characteristics of insecticide resistance in the fall armyworm, Spodoptera frugiperda (J.E. Smith). Pest. Biochem. Phys. 2003, 77, 1-11. [CrossRef]

13. Meagher, R.L.; Nuessly, G.S.; Nagoshi, R.N.; Hay-Roe, M.N. Parasitoids attacking fall armyworm (Lepidoptera: Noctuidae) in sweet corn habitats. Biol. Control 2016, 95, 66-72. [CrossRef]

14. Van Driesche, R.G.; Bellows, T.S. Biological Control; Chapman and Hall: New York, NY, USA, 1996.

15. Kenis, M.; Hurley, B.; Hajek, A.E.; Cock, M. Classical biological control of insect pests of trees-Facts and figures. Biol. Invasions 2017, 19, 3401-3417. [CrossRef]

16. Molina-Ochoa, J.; Carpenter, J.E.; Heinrichs, E.A.; Foster, J.E. Parasitoids and parasites of Spodoptera frugiperda (Lepidoptera: Noctuidae) in the Americas and Caribbean Basin: An inventory. Fla. Entomol. 2003, 86, 254-289. [CrossRef]

17. Estrada Vírgen, O.; Cambero Campos, J.; Robles Bermudez, A.; Rios Velasco, C.; Carvajal Cazola, C.; Isiordia Aquino, N.; Ruiz Cancino, E. Parasitoids and entomopathogens of the fall armyworm Spodoptera frugiperda (Lepidoptera: Noctuidae) in Nayarit, Mexico. Southwestern Entomol. 2013, 38, 339-344. [CrossRef]

18. Cock, M.J.W.; Bennett, F.D.; Hughes, I.W.; Simmonds, F.J.; Yaseen, M. A Review of Biological Control of Pests in the Commonwealth Caribbean and Bermuda up to 1982; Commonwealth Agricultural Bureaux: Wallingford, Oxfordshire, UK, 1985.

19. Lobo Lima, M.L.; van Harten, A. Luta biologica contra as pragas de cultures em Cabo Verde situaçao actual a programas futuros. Revista Investigaçáo Agraria CEA 1985, A1, 3-11. (In Portuguese)

20. Cave, R.D. Biology, ecology and use in pest management of Telenomus remus. Biocontrol News Inf. 2000, 21, 21-26. 
21. Gutierrez-Martinez, A.; Tolon-Becerra, A.; Lastra-Bravo, X.B. Biological control of Spodoptera frugiperda eggs using Telenomus remus Nixon in maize-bean-squash polyculture. Am. J. Agr. Biol. Sci. 2012, 7, $285-292$. [CrossRef]

22. Pomari, A.F.; Bueno, A.D.F.; Bueno, R.C.O.D.F.; Junior, M.; de Oliveiras, A.; Fonseca, A.C.P.F. Releasing number of Telenomus remus (Nixon) (Hymenoptera: Platygastridae) against Spodoptera frugiperda Smith (Lepidoptera: Noctuidae) in corn, cotton and soybean. Ciência Rural 2013, 43, 377-382. [CrossRef]

23. Vieira, N.F.; Pomari-Fernandes, A.; Lemes, A.A.; Vacari, A.M.; De Bortoli, S.A.; de Freitas Bueno, A. Cost of production of Telenomus remus (Hymenoptera: Platygastridae) grown in natural and alternative hosts. J. Econ. Entomol. 2017, 110, 2724-2726. [CrossRef]

24. Cave, R.D.; Acosta, N.M. Telenomus remus Nixon: Un parasitoide en el control biológico del gusano cogollero, Spodoptera frugiperda (Smith). Ceiba 1999, 40, 215-227. (In Spanish)

25. Figueiredo, M.L.C.; Della Lucia, T.M.C.; Cruz, I. Effect of Telenomus remus Nixon (Hymenoptera: Scelionidae) density on control of Spodoptera frugiperda (Smith) (Lepidoptera: Noctuidae) egg masses upon release in maize field. Rev. Bras. Milho Sorgo 2002, 1, 12-19. [CrossRef]

26. Pomari-Fernandes, A.; De Queiroz, A.P.; de Freitas Bueno, A.; Sanzovo, A.W.; De Bortoli, S.A. The importance of relative humidity for Telenomus remus (Hymenoptera: Platygastridae) parasitism and development on Corcyra cephalonica (Lepidoptera: Pyralidae) and Spodoptera frugiperda (Lepidoptera: Noctuidae) eggs. Ann. Entomol. Soc. Am. 2015, 108, 11-17. [CrossRef]

27. Polaszek, A.; Kimani, S.W. Telenomus species (Hymenoptera: Scelionidae) attacking eggs of pyralid pests (Lepidoptera) in Africa: A review and guide to identification. Bull. Entomol. Res. 1990, 80, 57-71. [CrossRef]

28. Polaszek, A.; Ayshford, T.; Yahya, B.E.; Fusu, L. Wallaceaphytis: An unusual new genus of parasitoid wasp (Hymenoptera: Aphelinidae) from Borneo. J. Nat. Hist. 2014, 48, 1111-1123. [CrossRef]

29. Cock, M.J.W.; Beseh, P.K.; Buddie, A.G.; Cafà, G.; Crozier, J. Molecular methods to detect Spodoptera frugiperda in Ghana, and implications for monitoring spread of invasive species in developing countries. Sci. Rep. 2017, 7. [CrossRef] [PubMed]

30. Folmer, O.; Black, M.; Hoeh, W.; Lutz, R.; Vrijenhoek, R. DNA primers for amplification of mitochondrial cytochrome c oxidase subunit I from diverse metazoan invertebrates. Mol. Mar. Biol. Biotech. 1994, 3 , 294-299.

31. Kumar, S.; Stecher, G.; Tamura, K. MEGA7: Molecular Evolutionary Genetics Analysis Version 7.0 for Bigger Datasets. Mol. Biol. Evo. 2016, 33, 1870-1874. [CrossRef] [PubMed]

32. Ratnasingham, S.; Hebert, P.D.N. A DNA-based registry for all animal species: The Barcode Index Number (BIN) System. PLoS ONE 2013, 8. [CrossRef]

33. Clark, K.; Karsch-Mizrachi, I.; Lipman, D.J.; Ostell, J.; Sayers, E.W. GenBank. Nucleic Acids Res. 2016, 44, 67-72. [CrossRef] [PubMed]

34. Tamura, K.; Nei, M. Estimation of the number of nucleotide substitutions in the control region of mitochondrial DNA in humans and chimpanzees. Mol. Biol. Evol. 1993, 10, 512-526.

35. Felsenstein, J. Confidence limits on phylogenies: An approach using the bootstrap. Evolution 1985, 39, 783-791. [CrossRef]

36. Hymenoptera Online. Available online: https://hol.osu.edu/index.html?id=3064 (accessed on 14 December 2018).

37. Hymenoptera Online. Available online: https://hol.osu.edu/spmInfo.html?id=OSUC\%2072859 (accessed on 14 December 2018).

38. Hay-Roe, M.M.; Nagoshi, R.N.; Meagher, R.L.; De Lopez, M.A.; Trabanino, R. Isolation and DNA barcode characterization of a permanent Telenomus (Hymenoptera: Platygastridae) population in Florida that targets fall armyworm (Lepidoptera: Noctuidae). Ann. Entomol. Soc. Am. 2015, 108, 729-735. [CrossRef]

39. Virgilio, M.; Backeljau, T.; Nevado, B.; De Meyer, M. Comparative performances of DNA barcoding across insect orders. BMC bioinformatics 2010, 11. [CrossRef] [PubMed]

40. Bowers, K.R. Telenomus podisi: One Species, or More? Master's Thesis, The Ohio State University, Columbus, OH, USA, 2015.

41. Wojcik, B.; Whitcomb, W.H.; Habeck, D.H. Host range testing of Telenomus remus (Hymenoptera: Scelionidae). Fla. Entomol. 1976, 59, 195-198. [CrossRef]

42. Sisay, B.; Simiyu, J.; Malusi, P.; Likhayo, P.; Mendesil, E.; Elibariki, N.; Wakgari, M.; Ayalew, G.; Tefera, T. First report of the fall armyworm, Spodoptera frugiperda (Lepidoptera: Noctuidae), natural enemies from Africa. J. Appl. Entomol. 2019. [CrossRef] 
43. Lesieur, V.; Lombaert, E.; Guillemaud, T.; Courtial, B.; Strong, W.; Roques, A.; Auger-Rozenberg, M.A. The rapid spread of Leptoglossus occidentalis in Europe: A bridgehead invasion. J. Pest. Sci. 2018, 92, 198-200. [CrossRef]

44. Polaszek, A.; Kimani-Njogu, S.W. Scelionidae. In African Cereal Stem Borers: Economic Importance, Taxonomy, Natural Enemies and Control; Polaszek, A., Ed.; CAB International: Wallingford, UK, 1998; pp. 259-264.

45. Gerling, D. The developmental biology of Telenomus remus Nixon (Hym.: Scelionidae). Bull. Entomol. Res. 1972, 61, 385-488. [CrossRef]

46. Bueno, R.C.O.D.F.; Carneiro, T.R.; Pratissoli, D.; Bueno, A.D.; Fernandes, O.A. Biology and thermal requirements of Telenomus remus reared on fall armyworm Spodoptera frugiperda eggs. Ciência Rural 2008, 38, 1-6. [CrossRef]

47. Pomari, A.F.; Bueno, A.D.F.; Bueno, R.C.O.D.F.; Menezes, A.D.O. Biological characteristics and thermal requirements of the biological control agent Telenomus remus (Hymenoptera: Platygastridae) reared on eggs of different species of the genus Spodoptera (Lepidoptera: Noctuidae). Ann. Entomol. Soc. Am. 2012, 105, 73-81. [CrossRef]

48. Queiroz, A.P.; de Freitas Bueno, A.; Pomari-Fernandes, A.; Grande, M.L.M.; Bortolotto, O.C.; da Silva, D.M. Quality control of Telenomus remus (Hymenoptera: Platygastridae) reared on the factitious host Corcyra cephalonica (Lepidoptera: Pyralidae) for successive generations. Bull. Entomol. Res. 2017, 107, 791-798. [CrossRef] [PubMed]

49. Nixon, G.E.J. LIV.—Some Asiatic Telenominæ (Hym., Proctotrupoidea). Annals Mag. Natl. Hist. 1937, 20, 444-475. [CrossRef]

50. Ashmead, W.H. Descriptions of new Hymenoptera from Japan. JSTOR 1904, 12, 65-84. [CrossRef]

51. Risbec, J.I. La faune entomologique des cultures au Sénégal et au Soudan Français E II Contribution á l'étude des Proctotrupidae; Travaux du Laboratoire d'Entomologie du Secteur Soudanais de Recherches, Gouvernment Général de l'Afrique Occidentale Française: Paris, France, 1950. (In French)

52. Raveendranath, S. Biology and behaviour of Telenomus spp. (Hymenoptera: Scelionidae) egg parasitoids, attacking Spodoptera spp. (Lepidoptera: Noctuidae). Ph.D. Thesis, Imperial College, University of London, London, UK, 1987.

53. Arakaki, N.; Noda, H.; Yamagishi, K. Wolbachia-induced parthenogenesis in the egg parasitoid Telenomus nawai. Entomol. Exp. Appl. 2000, 96, 177-184. [CrossRef]

(C) 2019 by the authors. Licensee MDPI, Basel, Switzerland. This article is an open access article distributed under the terms and conditions of the Creative Commons Attribution (CC BY) license (http://creativecommons.org/licenses/by/4.0/). 